\title{
ONCOLOGY
}

\section{Synthetic Phenolic Antioxidant TS-13 Suppresses the Growth of Lewis Lung Carcinoma and Potentiates Oncolytic Effect of Doxorubicin}

\author{
E. B. Men'shchikova ${ }^{1}$, N. K. Zenkov' ${ }^{1}$ P. M. Kozhin ${ }^{1}$, \\ A. V. Chechushkov ${ }^{1}$, A. V. Kovner ${ }^{1}$, M. V. Khrapova ${ }^{1}$, \\ N. V. Kandalintseva ${ }^{2}$, and G. G. Martinovich ${ }^{3}$
}

Translated from Byulleten'Eksperimental'noi Biologii i Meditsiny, Vol. 166, No. 11, pp. 592-597, November, 2018 Original article submitted June 28, 2018

\begin{abstract}
ROS are important intracellular messengers; their ambiguous role in malignant processes was demonstrated in many studies. The effects of a synthetic phenolic antioxidant sodium 3-(3'-tert-butyl-4'-hydroxyphenyl)propyl thiosulfonate sodium (TS-13) on the tumor growth and oncolytic properties of doxorubicin were studied in the experimental model of Lewis lung carcinoma in mice. In mice receiving TS-13 with drinking water $(100 \mathrm{mg} / \mathrm{kg})$, suppression of tumor growth by $32.3 \%$ was observed on day 21 after inoculation of Lewis lung carcinoma cells. Two-fold intraperitoneal injections of doxorubicin in a cumulative dose of $8 \mathrm{mg} / \mathrm{kg}$ were followed by inhibition of tumor growth by $49.5 \%$. Combined treatment with TS-13 and doxorubicin suppressed the tumor growth by $55.4 \%$. In contrast to doxorubicin, TS-13 inhibited NO generation by peritoneal macrophages. The results show the prospect of studying TS-13 in the context of overcoming drug-resistance of tumors.
\end{abstract}

Key Words: reactive oxygen metabolites; grafted Leis lung carcinoma; sulphur-containing phenolic antioxidant TS-13

ROS are important intracellular messengers that regulate transcription factors, protein kinases, and cell proliferation and differentiation and can induce apoptosis and necrosis. Enhanced ROS production is observed in various types of tumor cells. ROS activate the mechanisms of cell survival during hypoxia, enhance glucose metabolism, activate proliferation, and mediate resistance to chemotherapy [10]. ROS hyperproduction is associated with activation of endogenous mechanisms protecting from oxidative damage, such as redox-sen-

${ }^{1}$ Federal Research Center of Fundamental and Translational Medicine; ${ }^{2}$ Novosibirsk State Pedagogical University, Novosibirsk, Russia; ${ }^{3} \mathrm{Be}-$ larusian State University, Minsk, Republic of Belarus. Address for correspondence: lemen@centercem.ru. E. B. Men'shchikova sitive signal system of antioxidant-response element Keap1/Nrf2/ARE that controls a broad spectrum of antioxidant enzymes, level of intracellular glutathione, and mechanisms of xenobiotic detoxification [2]. Epidemiological studies show the negative correlation between the consumption of products enriched in phenolic antioxidants and risk of cancer development. However, numerous attempts of using vitamins with antioxidant properties to reduce the frequency of malignant tumors failed [7]. The role of phenolic antioxidants in the therapy of tumor patients is also not clear yet. These agents reduce the proliferative activity of tumor cells and suppress metastasizing, but on the other hand, they increase cell resistance to chemotherapy [15]. According to previous concept of 
redox-signaling, the effect of regulation of cell functional activity is determined by not only the type and concentration of cell antioxidants, but also intracellular localization of ROS-synthetizing systems. Local increase in ROS production in mitochondria is an important stage of activation of programmed cell death in tumor cells [5].

The analysis of the effects of water-soluble sulfurcontaining phenolic antioxidant 3-(3'-tert-butyl-4'hydroxyphenyl)propyl thiosulfonate sodium (TS-13) on the redox-properties and chemoresistance of tumor cells showed that this agent reduces redox-buffer capacity and effective redox-potential; cell sensitivity to doxorubicin increases under these conditions [4]. The anti-tumor effects of TS-13 can be related to its influence on mitochondria, activation of apoptosis-inducing mechanisms [5], and ability to trigger Keap1/Nrf2/ ARE system $[3,6]$. On the basis of these results, we proposed a biophysical model of regulation of apoptosis in tumor cells explaining the effects of redox-active antioxidants [4].

The aim of the present study was to confirm the antitumor effects of TS-13 in vivo on the model of Lewis lung carcinoma in mice.

\section{MATERIALS AND METHODS}

TS-13 was synthesized at the Research Institute of Chemistry of Antioxidants (Novosibirsk) [3]. Doxorubicin (Pfizer) for intravenous, intravesical, and intraarterial administration was used as the reference agent. Lewis lung carcinoma (LLC) served as an experimental model of malignant tumor [12]. Tumor cell strains were obtained from the Bank of Cell Cultures of the Research Institute of Fundamental and Clinical Immunology (Novosibirsk).

The experiment was performed on female $\mathrm{C} 57 \mathrm{Bl} / 6$ mice $(n=50)$ aging 2 months and weighing 21-23 g. The animals were obtained from the Breeding Center of the E. D. Goldberg Research Institute of Pharmacology and Regenerative Medicine (Tomsk). The animals were kept in accordance with the rules of the European Convention for the Protection of Vertebrate Animals used for Experimental and Other Scientific Purposes (Strasburg, 1986). They were housed 10 specimens per cage in a vivarium with normal light cycle and free access to water. The mice were randomized into 5 groups (10 animals per group): group 1, control (injections of $0.9 \% \mathrm{NaCl}$ solution); group 2, inoculation of LLC cells; group 3, inoculation of LLC cells, doxorubicin treatment; group 4, TS-13 in drinking water, inoculation of LLC cells; group 5, TS-13 in drinking water, inoculation of LLC cells, doxorubicin treatment.

A suspension of LLC cells $\left(2 \times 10^{5}\right.$ cells/mouse $)$ was intramuscularly administered into the upper third of the hip in $0.1 \mathrm{ml}$ of $0.9 \% \mathrm{NaCl}$ solution. The solution of doxorubicin hydrochloride was injected twice intraperitoneally in a dose of $4 \mathrm{mg} / \mathrm{kg}$ body weight on days 7 and 14 of tumor development $\left({ }^{4} / \mathrm{LD}_{10}\right.$; cumulative dose of $8 \mathrm{mg} / \mathrm{kg})$. TS-13 (100 mg/kg of body weight) was added to the drinking water 14 days before cell inoculation and up to the end of the experiment.

On day 21 of tumor growth, the mice were sacrificed and the tumor was isolated and weighed on analytical scales. Tumor size was measured in two perpendicular directions. In addition to the absolute weight of the tumor, its relative weight was calculated (\% of body weight). Tumor volume was estimated using the formula $\mathrm{V}=0.5 \times \mathrm{a} \times \mathrm{b}^{2}$, where $\mathrm{a}$ and $\mathrm{b}$ are max and min linear sizes of the tumor [12]. The index of tumor growth inhibition (TGI, \%) was calculated by the following formulas:

$$
\mathrm{TGI}_{\mathrm{M}}=\mathrm{M}_{\mathrm{c}}-\mathrm{M}_{\mathrm{t}} / \mathrm{M}_{\mathrm{c}} \times 100 \% \text { and } \mathrm{TGI}_{\mathrm{V}}=\mathrm{V}_{\mathrm{c}}-\mathrm{V}_{\mathrm{t}} / \mathrm{V}_{\mathrm{c}} \times 100 \% \text {, }
$$

where $M_{c}$ and $M_{t}$, medians of tumor weight under in the control and treatment groups, respectively; $\mathrm{V}_{\mathrm{c}}$ and $\mathrm{V}_{\mathrm{t}}$, medians of tumor volume in the control and treatment groups, respectively.

The specimens of primary tumor nodes from animals of each group were processed routinely for histological analysis: fixed in neutral 10\% formalin, dehydrated in ascending concentrations of alcohols, and embedded in a synthetic paraffine medium (HISTOMIX). The sections $(4 \mu)$ sliced on a rotation microtome (Microm) were stained with hematoxylin and eosin. Light microscopy was performed using an AxioImager A1 microscope with AxioCam MRc5 camera (Carl Zeiss).

The normality of distribution of quantitative data on the primary stage of statistical analysis was evaluated by the Shapiro-Wilk test. As the distribution differed from the normal, the data are presented as median $(\mathrm{Me})$ and interquartile intervals $(25 \% ; 75 \%)$. Intergroup differences were estimated by Dunn's test. The critical value of significance of the zero hypothesis $(p)$ was taken as 0.05 .

\section{RESULTS}

In animals receiving doxorubicin injections (group 3), considerable body weight loss was observed. On days 14 and 21 of the experiment, their body weight was lower than in the control (group 1) and non-treated (group 2) mice (Table 1). On the contrary, body weight of group 2 mice significantly increased on day 21 in comparison with the control $(p<0.05)$. The differences between groups 2 and 3 animals were just partly determined by smaller tumor size in group 3 mice (Table 2). The body weight of mice not treated with doxorubicin 
TABLE 1. Changes in Body Weight $(\mathrm{g})$ of Female C57BI/6 Mice during the Experiment (Me $(25 ; 75 \%)$

\begin{tabular}{|c|c|c|c|c|}
\hline \multirow{2}{*}{ Group } & \multicolumn{4}{|c|}{ Time period after tumor inoculation, days } \\
\hline & 0 & 7 & 14 & 21 \\
\hline Group 1 (intact control) & $\begin{array}{c}22.30 \\
(21.74 ; 22.92)\end{array}$ & $\begin{array}{c}22.71 \\
(22.00 ; 23.20)\end{array}$ & $\begin{array}{c}22.88 \\
(22.38 ; 23.15)\end{array}$ & $\begin{array}{c}22.80 \\
(22.10 ; 24.00)\end{array}$ \\
\hline Group 2 (LLC) & $\begin{array}{c}22.25 \\
(21.37 ; 23.13)\end{array}$ & $\begin{array}{c}22.01 \\
(21.57 ; 22.59)\end{array}$ & $\begin{array}{c}22.38 \\
(22.14 ; 24.29)\end{array}$ & $\begin{array}{c}24.10^{\star} \\
(23.50 ; 26.30)\end{array}$ \\
\hline Group 3 (LLC+doxorubicin) & $\begin{array}{c}22.43 \\
(22.09 ; 22.77)\end{array}$ & $\begin{array}{c}21.15 \\
(20.80 ; 22.20)\end{array}$ & $\begin{array}{c}20.90^{\star+} \\
(20.40 ; 21.24)\end{array}$ & $\begin{array}{c}21.10^{\star+} \\
(20.70 ; 21.50)\end{array}$ \\
\hline Group 4 (TS-13+LLC) & $\begin{array}{c}22.33 \\
(21.92 ; 22.73)\end{array}$ & $\begin{array}{c}22.59 \\
(22.24 ; 22.84)\end{array}$ & $\begin{array}{c}22.37 \\
(21.80 ; 22.80)\end{array}$ & $\begin{array}{c}23.50 \\
(22.30 ; 23.90)\end{array}$ \\
\hline $\begin{array}{l}\text { Group } 5 \\
\text { (Ts-13+LLC+doxorubicin) }\end{array}$ & $\begin{array}{c}22.61 \\
(22.22 ; 23.01)\end{array}$ & $\begin{array}{c}21.80 \\
(21.70 ; 22.10)\end{array}$ & $\begin{array}{c}21.10^{\star} \\
(20.70 ; 21.80)\end{array}$ & $\begin{array}{c}21.60^{*} \\
(21.20 ; 22.00)\end{array}$ \\
\hline
\end{tabular}

Note. Here and in Table 2: $p<0.05$ in comparison with *intact control, ${ }^{+}$non-treated animals.

TABLE 2. Changes in the Relative Body Weight, Weight and Volume of the Tumor in Female C57BI/6 Mice (Me (25; 75\%)

\begin{tabular}{|c|c|c|c|c|c|c|c|}
\hline Group & $\Delta \mathrm{M}, \mathrm{g}$ & $\begin{array}{l}\text { Tumor } \\
\text { weight, g }\end{array}$ & $\underset{\%}{\mathrm{TGI}}{ }_{\mathrm{M}}$ & $\begin{array}{l}\text { Relative tumor } \\
\text { weight, \% of } \\
\text { body weight }\end{array}$ & $\begin{array}{c}\text { Tumor } \\
\text { volume, } \\
\mathrm{mm}^{3}\end{array}$ & $\underset{\%}{\mathrm{TGI}_{\mathrm{V}},}$ & $\begin{array}{l}\text { NO } \\
\text { production, } \\
\text { arb. units }\end{array}$ \\
\hline Group 2 (LLC) & $\begin{array}{c}19.98 \\
(19.45 ; 22.18)\end{array}$ & $\begin{array}{c}4.01 \\
(3.94 ; 4.15)\end{array}$ & & $\begin{array}{c}16.94 \\
(14.86 ; 17.14)\end{array}$ & $\begin{array}{c}4786 \\
(4005 ; 5027)\end{array}$ & & $\begin{array}{c}1.27^{\star} \\
(1.26 ; 1.35)\end{array}$ \\
\hline $\begin{array}{l}\text { Group } 3 \\
\text { (LLC+doxorubicin) }\end{array}$ & $\begin{array}{c}18.99^{+} \\
(18.24 ; 19.17)\end{array}$ & $\begin{array}{c}2.03^{+} \\
(1.83 ; 2.35)\end{array}$ & 49.5 & $\begin{array}{c}9.59^{+} \\
(8.72 ; 11.33)\end{array}$ & $\begin{array}{c}2214^{+} \\
(2066 ; 2530)\end{array}$ & 54.9 & $\begin{array}{c}1.39 * \\
(1.22 ; 1.77)\end{array}$ \\
\hline $\begin{array}{l}\text { Group } 4 \\
\text { (TS-13+LLC) }\end{array}$ & $\begin{array}{c}20.55 \\
(19.53 ; 21.27)\end{array}$ & $\begin{array}{c}2.71^{\circ} \\
(2.17 ; 3.03)\end{array}$ & 32.3 & $\begin{array}{c}11.90^{\circ} \\
(9.69 ; 12.55)\end{array}$ & $\begin{array}{c}3071^{\circ} \\
(2654 ; 3681)\end{array}$ & 35.8 & $\begin{array}{c}1.08^{\circ} \\
(0.97 ; 1.27)\end{array}$ \\
\hline $\begin{array}{l}\text { Group } 5 \\
\text { (TS-13+LLC+doxorubicin) }\end{array}$ & $\begin{array}{c}19.68^{\circ} \\
(19.48 ; 20.18)\end{array}$ & $\begin{array}{c}1.79^{+} \\
(1.55 ; 1.91)\end{array}$ & 55.4 & $\begin{array}{c}8.32^{+} \\
(7.14 ; 9.45)\end{array}$ & $\begin{array}{c}1937^{+} \\
(1606 ; 2287)\end{array}$ & 59.5 & $\begin{array}{c}1.28 \\
(1.06 ; 1.74)\end{array}$ \\
\hline
\end{tabular}

Note. $\Delta \mathrm{M}$, body weight without tumor weight; ${ }^{\circ} p<0.05$ in comparison with animals not treated with TS-13. NO• production standardized to that in the control $1.00(0.81 ; 1.03)$.

and receiving TS-13 with drinking water (group 4) did not change throughout the experiment. In group 5 animals (doxorubicin intraperitoneally+TS-13 with drinking water), this parameter was below the control on days 14 and 21 (Table 1), although this decrease was less pronounced than in group 3. The inhibition of cachectic effect of doxorubicin by monophenol TS13 was confirmed by the higher body weight (without tumor weight) in group 5 in comparison with the group 3 (Table 2).

Tumor nodes developed at the site of injection of cell suspension in animals of all experimental groups. In group 5 animals, macroscopic examination showed smaller destruction zones and hemorrhages in the tumor nodes in comparison with other groups. The analysis of tumor size showed that TS-13 significantly inhibited its growth (group 4), which manifested in lower absolute and relative tumor weight and volume in comparison with the negative control (group 2; Table 2). This effect was similar and synergic to the effect of doxorubicin (group 3). Treatment with TS-13 also significantly affected NO generation by peritoneal macrophages. This parameter significantly increased in group 2 animals with inoculated tumor relative to intact control. Doxorubicin administration did not abolish this effect (group 3). However, the ability of macrophages in group 4 mice to synthesize NO was similar to that in intact control and significantly lower than in group 2 mice (Table 2).

Microscopy of the primary tumor nodes in group 2 mice showed that the node tissue consisted of highly polymorphic atypical tumor cells. Numerous cells with large nuclei and mitotic cells were also seen. Extensive hemorrhages, areas of edema and necrosis were observed. It should be noted that these destruction areas had no certain location and mostly surrounded the tumor nodes (Fig. 1). Similar morphological pattern was observed in group 3 mice. TS-13 in groups 4 and 5 animals produced strong oncostatic effect, which manifested in a decrease in the volume 

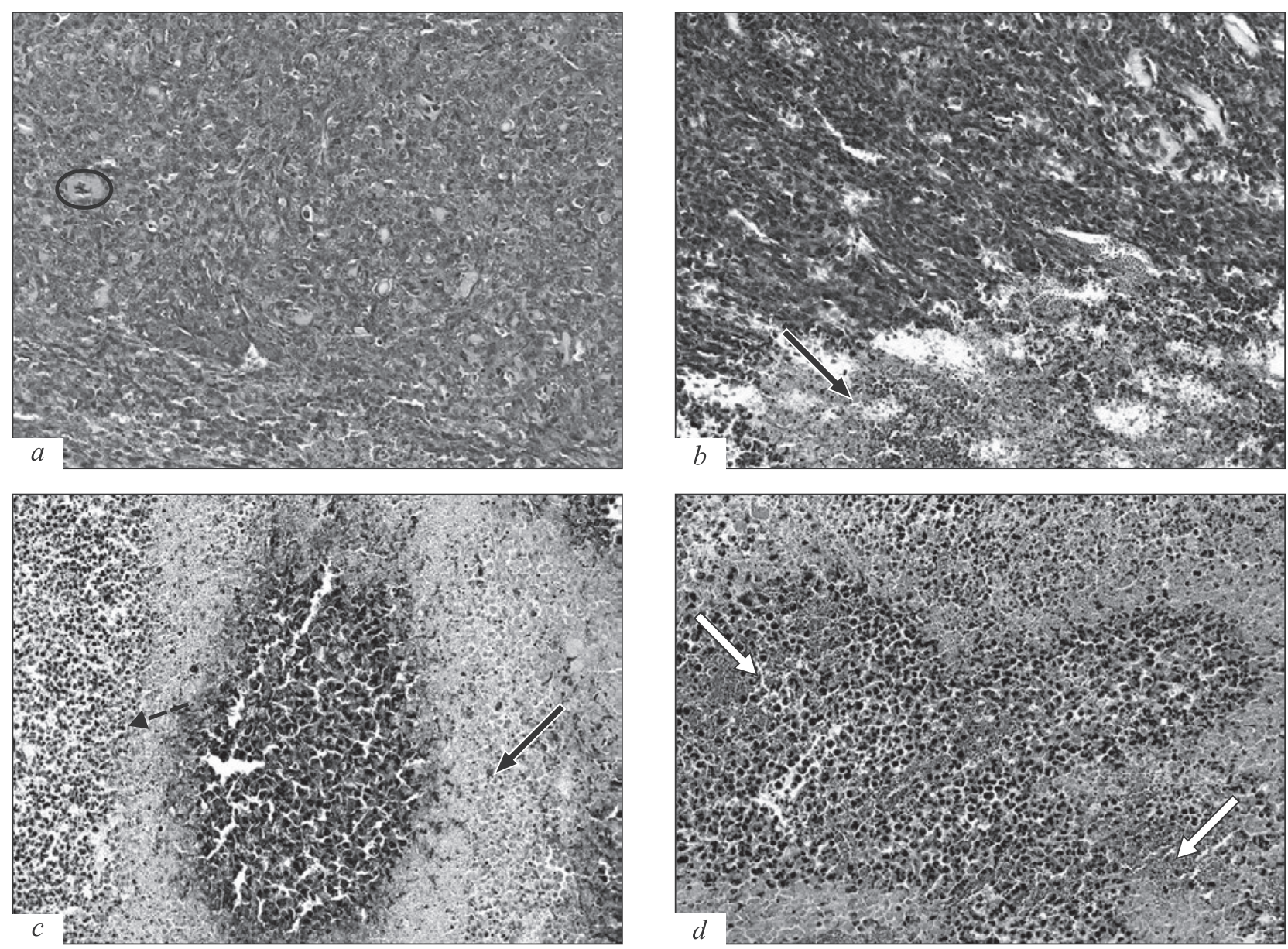

Fig. 1. Representative LLC samples from group 2 mice. Giant atypical tumor cells during in mitosis (shown with a circle), areas of destruction and necrosis (shown with arrows), areas of inflammatory infiltration (shown with dotted arrow) and hemorrhages (shown with white arrows), $\times 200$.

of destruction (necrosis, edema, and hemorrhages), less pronounced cell polymorphism, and the absence of inflammatory infiltration in surrounding muscle tissues.

Antitumor effect has been observed in many plant-derived phenols and it is mediated by multiple mechanisms. One of the main mechanisms of this effect is based on activation of the Keap1/Nrf2/ARE system [14]. The networks of transcriptional programs regulated by Nrf2 factor (mainly antioxidant and detoxication programs) enable cell adaptation and survival under various stressful conditions. This, together with its anti-inflammatory action and modulation of mitochondrial function and intermediary metabolism, determines the chemopreventive effects of Nrf2 and its ability to suppress carcinogenesis at the promotion stage [8]. On another hand, cells of already formed tumor can effectively use Nrf2 for self-protection. High activity of this protein in various samples of malignant tumors correlates to the negative prognosis for therapy and reduced life duration of patients [9].
The role of $\mathrm{NO} \cdot$ is also ambiguous $[10,13]$. It is known that the development of many types of tumors is associated with the increased expression of inducible NO synthase and $\mathrm{NO} \cdot$ production by macrophages. On one hand, these processes are related to the inflammatory response of organism, but on the other, excessive oxidative stress (distress) and inflammation form a vicious circle generating tumor microsurrounding and promoting its growth due to the ability of NO - to stimulate angiogenesis, suppress apoptosis of tumor cells, and promote tumor cells escape from immune control. Both anti-NO•- and $\mathrm{NO} \bullet$-based types of antitumor therapy are effective in various preclinical models [13]. Interestingly, the induction of Keap 1/ $\mathrm{Nrf2/ARE}$ system in activated macrophages is used for self-defense of these cells against produced NO• [11].

Thus, our study showed that TS-13 not only inhibits tumor growth, but also potentiated the effect of doxorubicin. These data are in line a previous report [1], where TS-13 enhanced the effects of cytostatic cyclophosphamide and increases survival of animals 
with lymphocytic leukemia P-388. The effects of redox-active substances, particularly phenols, are not limited by modulation of the Keap1/Nrf2/ARE signal system; they also influence other transcription factors and oncoregulators [14], which inspires further investigations of these substances and development of theoretical concepts of the interactions between various redox-sensitive signal systems and their roles in the progression of tumor processes.

The experiments were performed on the equipment of the Common Use Center "Modern Optic Systems" of the Federal Research Center of Fundamental and Translational Medicine.

\section{REFERENCES}

1. Bogatyrenko TN, Sashenkova TE, Mishchenko DV, Kandalintseva NV. Sulfur-containing phenolic antioxidants increasing antitumor efficiency of cyclophosphamide and its combination with nitric oxide donor. Rus. Chem. Bull. 2018;67(4):700-704.

2. Zenkov NK, Kozhin PM, Chechushkov AV, Menshchikova EB, Martinovich GG, Kandalintseva NV. Mazes of Nrf2 regulation. Biochemistry (Moscow). 2017;82(5):556-564.

3. Zenkov NK, Menshchikova EB, Kandalintseva NV, Oleynik AS, Prosenko AE, Gusachenko ON, Shklyaeva OA, Vavilin VA, Lyakhovich VV. Antioxidant and antiinflammatory activity of new water-soluble sulfur-containing phenolic compounds. Biochemistry (Moscow). 2007;72(6):644-651.

4. Martinovich GG, Martinovich IV, Vcherashniaya AV, Zenkov NK, Cherenkevich SN, Menshchikova EB, Kandalintseva NV. Mechanisms of Redox Regulation of Chemoresistance in Tumor Cells by Phenolic Antioxidants. Biophysics. 2017;62(6):942-949.

5. Martinovich GG, Martinovich IV, Cherenkevich SN, Zenkov NK, Menshchikova EB, Kandalintseva NV. Phenolic anti- oxidant TS-13 regulating ARE-driven genes induces tumor cell death by a mitochondria-dependent pathway. Biophysics. 2015;60(1):94-100.

6. Menshchikova EB, Tkachev VO, Zenkov NK, Lemza AE, Sharkova TV, Kandalintseva NV. Anti-inflammatory activity of TS-13, ARE-inducing phenol antioxidant. Bull. Exp. Biol. Med. 2013;155(3):366-369.

7. Anantharaju PG, Gowda PC, Vimalambike MG, Madhunapantula S.V. An overview on the role of dietary phenolics for the treatment of cancers. Nutr. J. 2016;15(1):99.

8. Dinkova-Kostova AT, Fahey JW, Kostov RV, Kensler TW. KEAP1 and done? Targeting the NRF2 pathway with sulforaphane. Trends Food Sci. Technol. 2017;69(Pt B):257-269.

9. Kitamura H, Motohashi H. NRF2 addiction in cancer cells. Cancer Sci. 2018;109(4):900-911.

10. Kumari S, Badana AK, Gavara MM, Gugavalath S, Malla R. Reactive oxygen species: a key constituent in cancer survival. Biomark. Insights. 2018;13. ID 1177271918755391. doi: $10.1177 / 1177271918755391$.

11. Lok HC, Sahni S, Jansson PJ, Kovacevic Z, Hawkins CL, Richardson DR. A nitric oxide storage and transport system that protects activated macrophages from endogenous nitric oxide cytotoxicity. J. Biol. Chem. 2016;291(53):27,042-27,061.

12. Onishi H, Fukasawa A, Miatmoko A, Kawano K, IkeuchiTakahashi Y, Hattori Y. Preparation of chondroitin sulfateadipic acid dihydrazide-doxorubicin conjugate and its antitumour characteristics against LLC cells. J. Drug Target. 2017;25(8):747-753.

13. Rahat MA, Hemmerlein B. Macrophage-tumor cell interactions regulate the function of nitric oxide. Front. Physiol. 2013;4:144. doi: 10.3389/fphys.2013.00144.

14. Rajagopal C, Lankadasari MB, Aranjani JM, Harikumar KB. Targeting oncogenic transcription factors by polyphenols: A novel approach for cancer therapy. Pharmacol. Res. 2018;130:273-291.

15. Russo GL, Tedesco I, Spagnuolo C, Russo M. Antioxidant polyphenols in cancer treatment: Friend, foe or foil? Semin. Cancer Biol. 2017;46:1-13. 